\title{
Variasi Genetik Troides helena (Lepidoptera: Papilionidae) Berdasarkan Gen COI (Cytochrome Oxydase I)
}

\author{
Claudius F. Kairupan a*, Roni Koneri a, Trina E. Tallei a \\ aJurusan Biologi, FMIPA, Unsrat, Manado
}

\begin{tabular}{l}
\hline K A T A K U N C I \\
\hline variasi genetik \\
Gen COI \\
Troides helena
\end{tabular}

\begin{abstract}
A B S T R A K
Kupu-kupu Troides helena (Kupu-kupu Raja) merupakan salah satu spesies langka yang dilindungi. Eksploitasi yang berlebihan, serta alih fungsi hutan menjadi ancaman bagi kehidupan kupu-kupu ini. Penelitian ini dilakukan untuk mengetahui variasi pada gen cytochrome $\mathrm{C}$ oxidase I Troides helena yang diperoleh dari dua lokasi yang berbeda, yaitu Gunung Tumpa dan Gunung Dua-sudara. Analisis sekuens menunjukkan adanya perbedaan satu pasang basa nukleotida dari kedua spesimen tersebut. Selain itu, variasi juga ditunjukan pada sampel yang diperoleh dari basis data GenBank dengan adanya perbedaan 7-8 pasang basa nukleotida dengan spesimen pada penelitian ini. Hasil perhitungan jarak genetik menunjukkan bahwa meskipun secara geografis spesimen-spesimen uji ini berasal dari lokasi yang berjauhan, variasi genetik masih berada dalam kisaran variasi intraspesies.
\end{abstract}

K E Y W O R D S

genetic variation

COI gene

Troides helena

\begin{abstract}
A B S T R A C T
Troides helena (Common Birdwing) is listed as one of endangered and protected butterfly species. Excessive exploitation and forest conversion have become threat to the life of this butterfly. This study was conducted to determine the genetic variation of Troides helena obtained from Mt. Tumpa and Mt. Dua-sudara based on cytochrome $\mathrm{C}$ oxidase I gene. Sequence analysis shows one nucleotide difference between these two specimens. Moreover, genetic variation also has been shown by comparing these two specimen with other Troides helena obtained from database in GenBank. There are 7-8 nucleotides differences among tested specimens. The result of genetic distance calculations indicates that although geographically these test specimens derived from remote locations, the genetic variation is still within the range of intraspecific variation.
\end{abstract}

TERSEDIA ONLINE

29 juli 2015
1. Pendahuluan

Sulawesi Utara memilliki tingkat keanekaragaman hewan yang tinggi di Indonesia, salah satunya adalah keanekaragaman kupu-kupu (Koneri dan Saroyo, 2012). Kupu-kupu memiliki peran penting sebagai pembantu penyerbukan bunga atau pollinator (Duara et al., 2014). Kupukupu juga sangat rentan terhadap perubahan lingkungan sehingga dapat dijadikan sebagai bioindikator perubahan kualitas lingkungan (Basset et al., 2012). Kupu-kupu Troides helena banyak dicari oleh kolektor untuk dijadikan koleksi, sehingga kupu-kupu ini memiliki nilai jual yang tinggi (Ngatimin et al., 2014). Kondisi tersebut memicu perburuan dan eksploitasi secara berlebihan yang tidak terkendali. Selain itu, pembukaan lahan dan alih fungsi hutan untuk keperluan ekonomi menjadi salah satu faktor utama hilangnya habitat kupu-

*Corresponding author: Jurusan Biologi FMIPA UNSRAT, Jl. Kampus Unsrat, Manado, Indonesia 95115; Email address: claudiuskairupan@yahoo.com Published by FMIPA UNSRAT (2015) 
kupu (Basset et al., 2012). Apabila hal tersebut terus terjadi, maka berakibat penyusutan populasi kupu-kupu terutama Troides helena, sehingga dapat menyebabkan kepunahan. Karena itu pemerintah melindungi Troides helena melalui PP No. 7 Tahun 1999. Spesies ini juga termasuk dalam daftar Appendix II CITES, dengan demikian perdagangannya harus merupakan hasil penangkaran (Nurjannah, 2010).

Keanekaragaman genetik suatu populasi sangat penting untuk dikonservasi untuk mencegah tekanan inbreeding (Hedrick dan Kalinowski, 2000). Suatu populasi dapat beradaptasi terhadap perubahan yang terjadi di lingkungan sekitar disebabkan oleh adanya variasi keanekaragaman genetik (Dharmayanti, 2011). Salah satu alternatif untuk mempelajari keanekaragaman genetik adalah dengan menggunakan gen $\mathrm{CO}$ (Cytochrome $c$ oxidase I) yang bertindak sebagai kode batang DNA (DNA Barcode) untuk spesies hewan (Folmer et al., 1994). Metode DNA Barcoding dianggap cepat, konsisten dan dapat dipertanggungjawabkan sehingga sangat penting dalam membantu penelitian biologi konservasi dan keanekaragaman (Hebert et al., 2003). Telah banyak penelitian dengan menggunakan gen $\mathrm{CO}$ pada berbagai macam spesies dalam filum arthropoda lain, misalnya laba-laba (Emily et al., 2009), udang (Pujawan et al., 2012) dan ngengat (Jin et al., 2013).

Penelitian mengenai variasi genetik terhadap kupu-kupu Troides helena di beberapa daerah di Sulawesi Utara perlu dilakukan untuk tujuan konservasi. Spesimen diperoleh dari Gunung Tumpa dan daerah luar kawasan Tangkoko (Gunung DuaSudara). Penelitian ini bertujuan untuk mengetahui variasi genetik gen COI Troides helena yang diperoleh dari Gunung Tumpa dan Gunung DuaSudara. Lokasi dipilih berdasarkan aktivitas yang ada di daerah tersebut. Masing-masing tempat tersebut telah dilakukan pemanfaatan untuk kepentingan sosial dan ekonomi yang mungkin dapat menjadi ancaman terhadap populasi Troides helena (Kurniawan et al., 2008; Wowor, 2014).

\section{Metode}

\subsection{Isolasi DNA Troides helena}

Isolasi DNA dilakukan menggunakan Multisource Genomic DNA Miniprep Kit (Axygen) sesuai dengan prosedur (Lubenow et al., 2008; Davenport, 2014) dan dimodifikasi berdasarkan Kolondam et al. (2013). DNA mitokondria diekstrak dari pangkal kaki yang terhubung dengan abdomen untuk menghindari kontaminasi (Laiho dan Stahls, 2013). Modifikasi dilakukan untuk memaksimalkan ekstraksi DNA Troides helena dengan meningkatkan waktu lisis sel dari 10 menit menjadi 2 jam pada suhu $60^{\circ} \mathrm{C}$.

\subsection{Amplifikasi Gen COI dengan Teknik PCR}

Gen COI diperbanyak dengan metode PCR (Handoyo dan Rudiretna, 2000). Primer gen COI yang digunakan yaitu Lep_F1 (5'-ATT CAA CCA ATC ATA AAG ATAT- 3') dan Lep_R1 (5'-TAA ACT TCT GGA TGT CCA AAAA- 3') (Hebert et al., 2004; Ashfaq et al., 2013). Dengan menggunakan $5 x$ firepool PCR Master Mix Ready-to-load (Solis BioDyne), komponen yang dicampur untuk amplifikasi gen COI yaitu $20 \mu \mathrm{l}$ Go Taq, $1.5 \mu \mathrm{l}$ primer forward, $1.5 \mu \mathrm{l}$

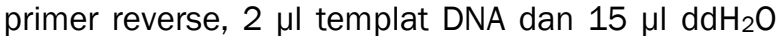
(air terdeionisasi). Modifikasi campuran mengikuti kondisi optimal reaksi penelitian terdahulu (Kolondam et al., 2013). Pengaturan suhu pada mesin PCR untuk amplifikasi gen COI mengikuti kondisi reaksi yang dilakukan oleh Davenport (2014), yaitu denaturasi awal pada suhu $94^{\circ} \mathrm{C}$ selama 1 menit. Amplifikasi dilakukan sebanyak 35 siklus dengan suhu $95^{\circ} \mathrm{C}$ selama 30 detik untuk denaturasi, $50^{\circ} \mathrm{C}$ selama 30 detik untuk penempelan primer pada DNA templat dan $72^{\circ} \mathrm{C}$ selama 45 detik untuk pemanjangan DNA. Proses amplifikasi dilakukan menggunakan alat $P C R$ Personal (Biometra). Proses sekuensing dilakukan oleh penyedia jasa sekuensing $1^{\text {st }}$ BASE Malaysia.

\subsection{Analisis Data}

Hasil sekuensing berupa kromatogram data urutan sekuens DNA, disunting dengan menggunakan progam software komputer Geneious v5.6.4 (Kearse et al., 2012; Tallei dan Kolondam, 2015). Untuk mendapatkan keakuratan yang sesuai dalam pengolahan data, penghapusan urutan data DNA dilakukan di bagian awal, sepanjang kurang lebih 30 nukleotida. Utas hasil sekuensing yang menggunakan primer forward dan reverse dirakit dan diedit. Utas reverse dilakukan proses reverse and complement, kemudian dipadukan dengan utas forward menggunakan MUSCLE (Multiple Sequence Comparison by Log-Expectation) yang terintegrasi dalam Geneious v5.6.4. Sekuen diubah dalam bentuk FASTA (fast alignment) untuk dibandingkan dengan sekuen-sekuen kerabat terdekat Troides helena yang diambil dari GenBank (www.ncbi.nlm.nih.gov). Penjajaran sekuens DNA dilakukan dengan menggunakan software Multalin pada situs http://multalin.toulouse.inra.fr/multalin/ (Corpet, 1988), kemudian penentuan reading frame untuk penjajaran asam amino dilakukan dengan menggunakan expasy translate tool pada situs http://web.expasy.org, dan dianalisis menggunakan Geneious. Pohon filogenetik dikonstruksi dengan menggunakan metode Neighbor-joining dan jarak genetik dianalisis menggunakan metode Tamura-Nei yang terintegrasi dalam Geneious v5.6.4.

\section{Hasil dan Pembahasan}

Amplifikasi dari ekstraksi DNA COI sampel Troides helena dari Gunung Tumpa (Kode sampel ThelenaBT) dan Gunung Dua-sudara (Kode sampel ThelenaBB) dengan teknik PCR, memperlihatkan hasil pola pita yang terlihat cukup jelas (Gambar 1). 
Berdasarkan ukuran DNA ladder dengan panjang $1 \mathrm{~kb}$ (10.000 bp) sebagai pembanding, menunjukan panjang gen COI kedua sampel kupu-kupu di lokasi berbeda, ThelenaBT dan ThelenaBB yang berhasil teramplifikasi berada pada ukuran 684bp.

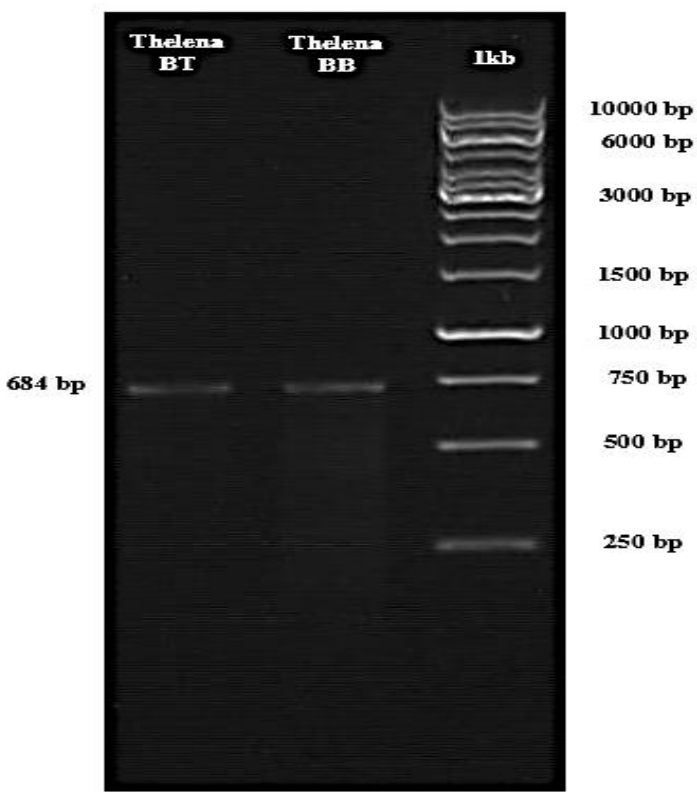

Gambar 1. Hasil amplifikasi fragmen gen COI dari sampel kupu-kupu Troides helena di lokasi yang berbeda menggunakan primer Lep F1 dan Lep R1.

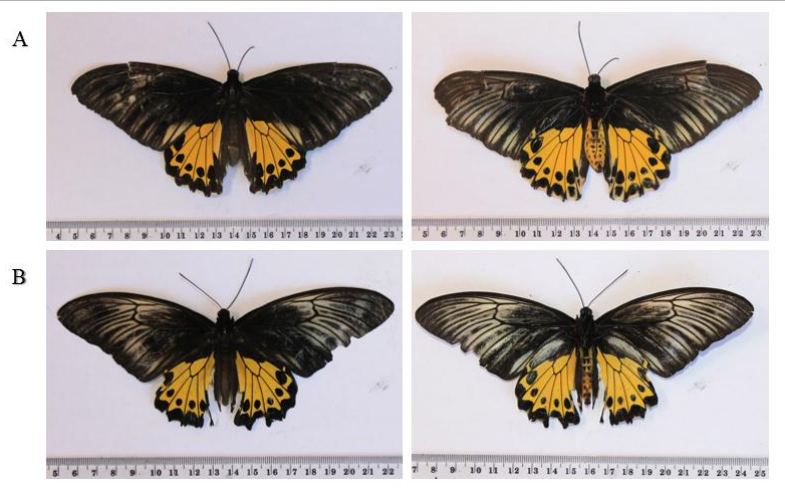

Gambar 2. (A). Sampel Troides helena dari Gunung Tumpa (Kode sampel ThelenaBT) (kiri tampak dorsal, kanan tampak ventral), (B). Sampel Troides helena dari Gunung Dua-sudara (Kode sampel ThelenaBB) (kiri tampak dorsal, kanan tampak ventral).

Penjajaran kedua sampel dengan menggunakan program Multalin (Corpet, 1988) memperlihatkan adanya variasi meskipun hanya pada satu basa nukleotida (Gambar 3), yaitu ThelenaBT memiliki basa A (Adenin) sedangkan ThelenaBB memiliki basa $G$ (Guanin). Kesamaan urutan sekuens kedua sampel adalah 99.83\%. Perbedaan satu basa nukleotida mempengaruhi asam amino yang disandi oleh gen tersebut (Gambar 3.C).

A. Thelenver

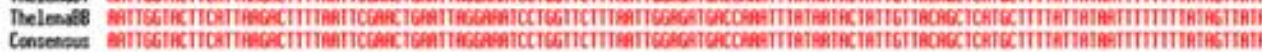

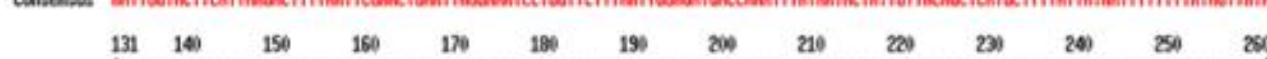

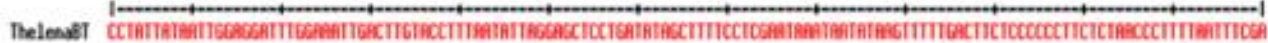

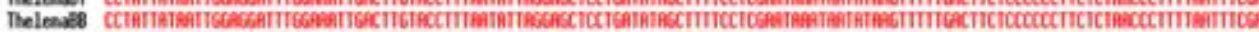

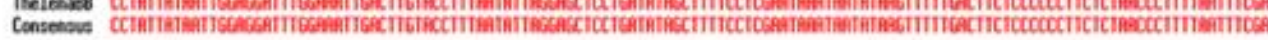

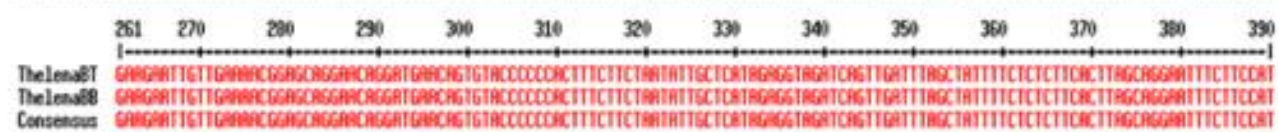

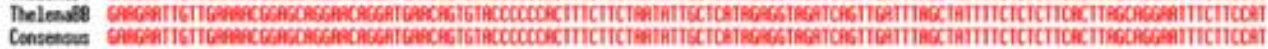

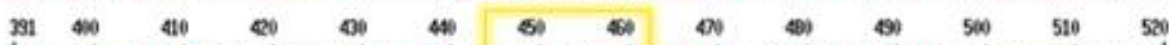

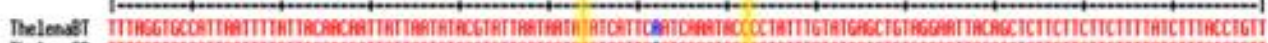

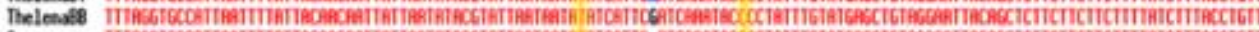

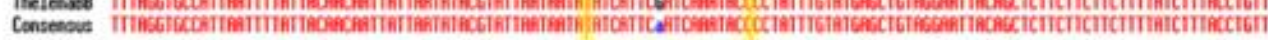

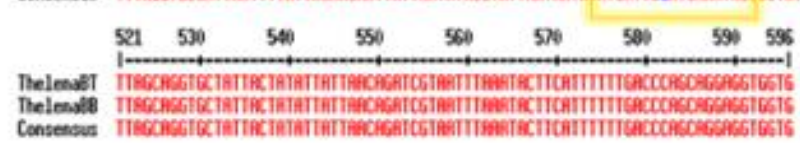

B.

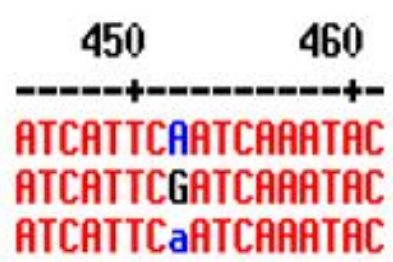

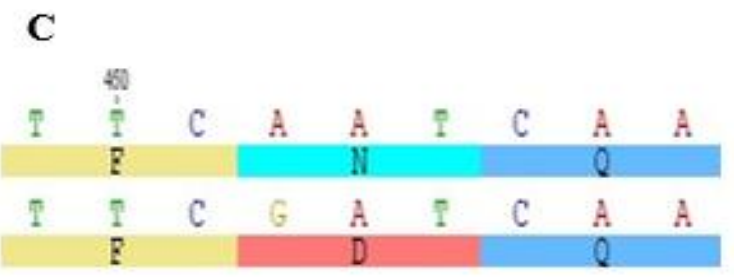

Gambar 3. (A). Penjajaran urutan sekuens Thelena BT dan ThelenaBB menggunakan program Multalin, (B). Perbesaran lokasi perbedaan nukleotida pada gen COI sampel ThelenaBT dan ThelenaBB, (C). Perbedaan asam amino pada gen COI sampel ThelenaBT dan ThelenaBB menggunakan Geneious. 
ThelenaBT memiliki triplet basa nukleotida AAT yang mengkodekan asam amino Aspargin (N) bersifat polar, sedangkan ThelenaBB memiliki triplet basa nukleotida CAT yang mengkodekan asam amino Asam Aspartat (D) yang juga bersifat polar. Berubahnya basa nukleotida yang kemudian mengubah asam amino yang dikodekan disebabkan oleh mutasi titik. Tidak adanya mekanisme pemulihan (proofreading) pada DNA mitokondria, mengakibatkan presentase terjadinya kesalahan pada saat replikasi atau transkripsi menjadi tinggi, yang kemudian berakibat pada perubahan sekuens asam amino yang dikodekan (Hawkes et al., 2004; Murray et al., 2014).

Sampel kerabat terdekat yang diperoleh dari GenBank berasal dari berbagai lokasi yang berbeda. KF226655.1 berasal dari Malaysia, EF514456.1 berasal dari India dan EF514446.1 berasal dari Indonesia (Gambar 4).

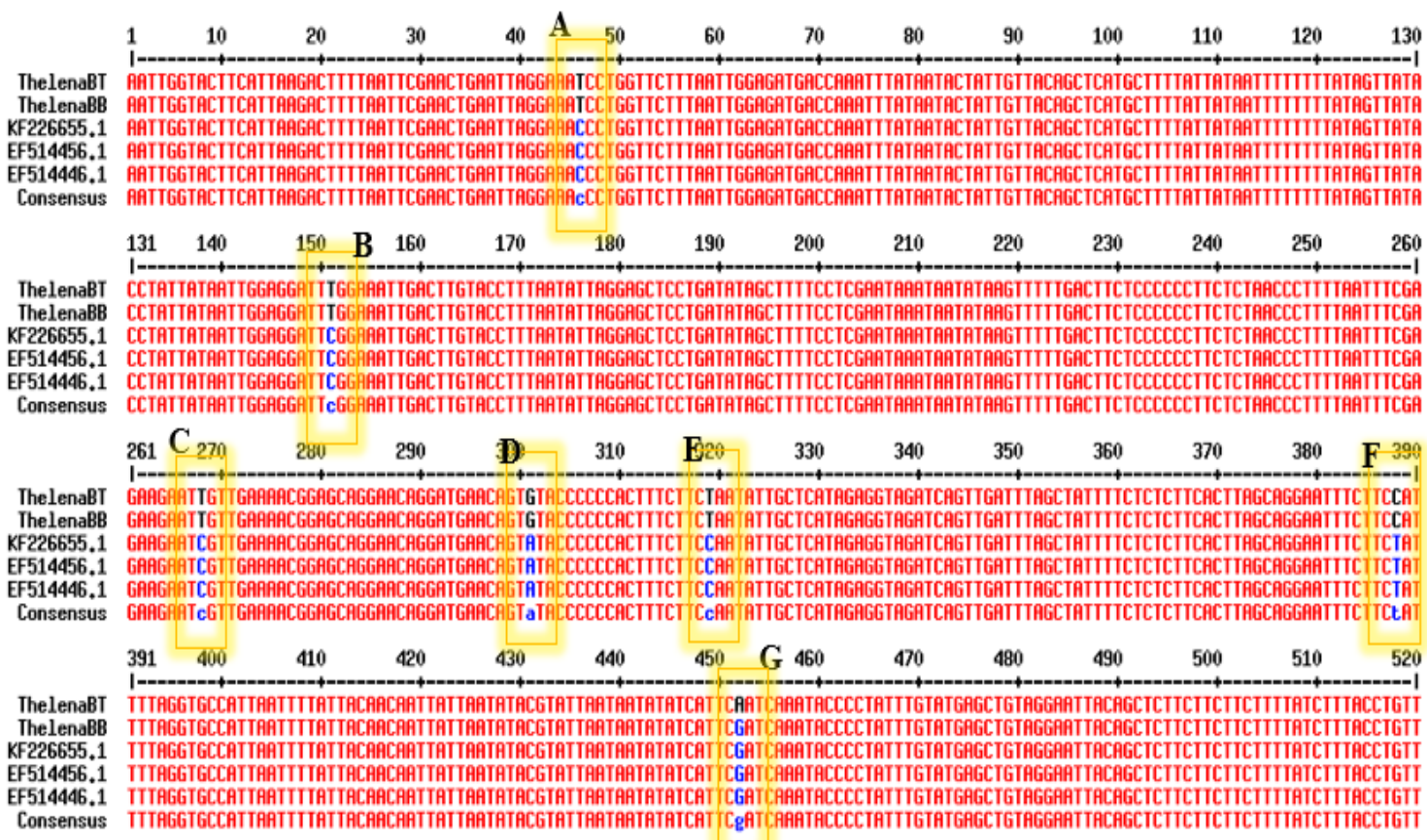

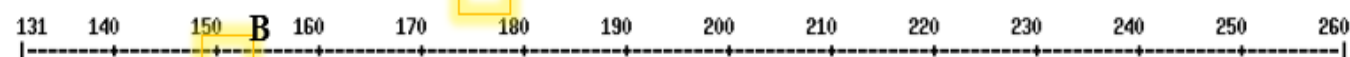

$$
\begin{array}{lllllllll}
521 & 530 & 540 & 550 & 560 & 570 & 580 & 590 & 596
\end{array}
$$

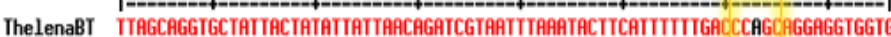

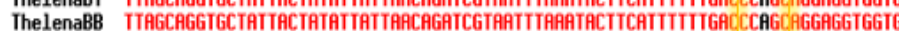

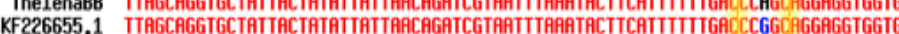

KF51455.1

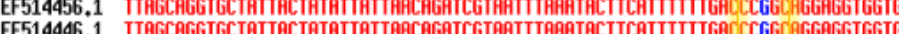

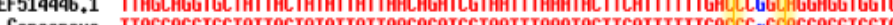

H

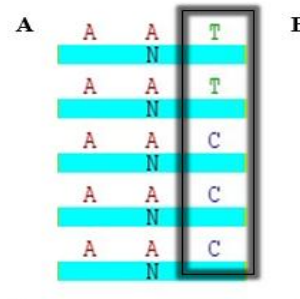

$\mathbf{E}$

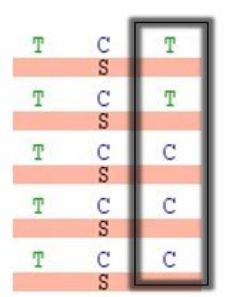

B

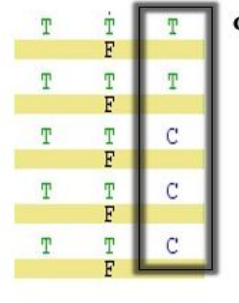

$\mathbf{F}$

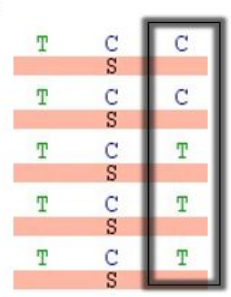

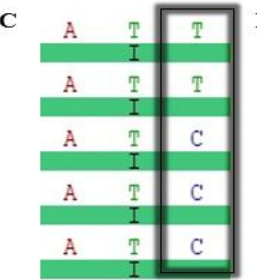

G

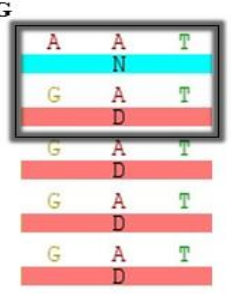

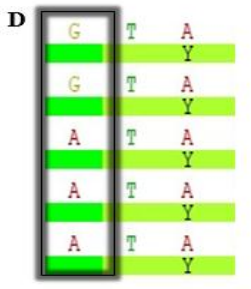

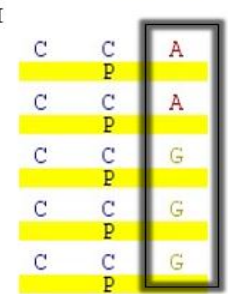

Gambar 4. Penjajaran urutan sekuens $\mathrm{COI}$ yang memperlihatkan perbedaan basa nukleotida yang bervariasi meskipun sedikit variasi pada tingkat asam amino. (A, B, C, D, E, F dan H). Menunjukan adanya variasi basa nukleotida yang tidak mempengaruhi asam amino yang dikodekan (Mutasi Sinonim). (G). Menunjukan adanya variasi pada tingkat asam amino dengan adanya perubahan pada nukleotida (Mutasi Titik). 
Tiga sampel kerabat terdekat yang diambil dari GenBank memiliki kesamaan urutan sekuens 100\%. Urutan sekuens ThelenaBT dan ThelenaBB memiliki perbedaan dengan sekuens sampel lainnya dari GenBank. Sampel KF226655.1 (Malaysia), EF514456.1 (India) dan EF514446.1 (Indonesia) memiliki perbedaan 8 basa nukleotida dengan ThelenaBT dan memiliki perbedaan 7 basa nukleotida dengan ThelenaBB. Sampel ThelenaBB memiliki asam amino dan susunan triplet nukleotida yang sama dengan sampel dari GenBank karena tidak adanya perubahan nukleotida pada urutan sekuens tersebut. Perubahan basa nukleotida tanpa mengubah asam amino yang dikodekan disebabkan oleh mutasi sinonim, mutasi ini tetap menghasilkan asam amino yang sama meskipun satu pasang basa nukleotida berubah (Zhou et al., 2010). Sedangkan sampel ThelenaBT memiliki variasi nukleotida yang mengubah susunan asam aminonya (Gambar 4.G). Berubahnya basa nukleotida yang kemudian mengubah asam amino yang dikodekan disebabkan oleh mutasi titik (Hawkes et al., 2004).

Mutasi menjadi penyebab utama perbedaan variasi nukleotida pada gen $\mathrm{COI}$, sehingga menyebabkan variasi pada susunan nukleotida, variasi yang kecil dapat mempengaruhi keidentikan suatu spesies dan bahkan dapat mempengaruhi susunan asam amino yang mengkodekan protein tertentu (Mattern et al., 2009). Perubahan geografis menyebabkan hambatan pada suatu sistem populasi yang dipisahkan, sehingga penyebaran spesies menjadi sulit untuk dilakukan. Sistem populasi yang terpisah akan sulit mempertahankan gen mereka dengan spesies yang dulunya dalam populasi yang sama namun terpisah, akibatnya sistem evolusi mereka akan terpisah (Simonsen et al., 2010; Nadeau et al., 2015).

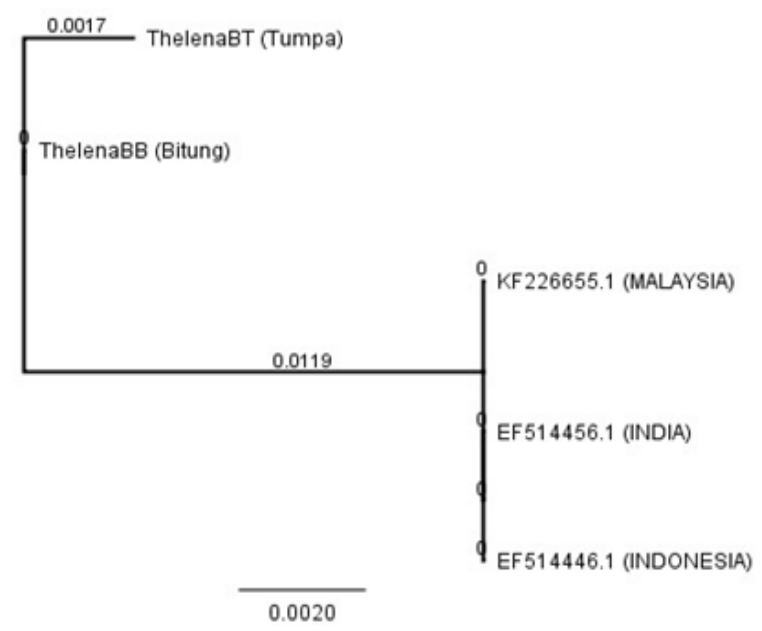

Gambar 5. Pohon filogenetik Troides helena dan beberapa kerabatnya dari GenBank berdasarkan gen COI, dikonstruksi menggunakan metode NeighborJoining memperlihatkan skala laju unit substitusi basa 0.0020 .
Pohon filogenetik memperlihatkan skala laju unit substitusi basa nukleotida 0.0020 (Gambar 5). Sampel EF514456.1, EF514446.1 dan KF226655.1 memiliki laju substitusi basa nukleotida yang berada pada angka 0.0119, jauh lebih tinggi dibandingkan dengan sampel ThelenaBT dengan angka 0.0017 dan ThelenaBB dengan angka 0 . Identiknya panjang cabang menunjukan spesies memiliki rata-rata laju substitusi basa nukleotida yang sama dalam hitungan waktu tertentu. Sebaliknya, perbedaan panjang cabang menunjukan perubahan pada laju substitusi basa nukleotida, sehingga jumlah perubahan substitusi basa nukleotida dalam hitungan waktu tertentu akan lebih besar jika cabang semakin panjang (Dharmayanti et al., 2011).

Dengan menggunakan software geneious v5.6.4 untuk mengetahui jarak genetik sampel (Tabel 1), menunjukan jarak genetik ( $p$-distance) sampel ThelenaBT (Gunung Tumpa) dengan ThelenaBB (Dua-Sudara Bitung) yaitu 0.002. ThelenaBT dibandingkan dengan kerabat dekatnya di tiga lokasi geografi yang berbeda yaitu 0.014 dan ThelenaBB dibandingkan dengan kerabat dekatnya di tiga lokasi geografi yang berbeda yaitu 0.012, Sedangkan perbedaan jarak genetik untuk tiga sampel yang berasal dari GenBank adalah 0. Jarak genetik COI (intraspecific p-distance) pada berbagai jenis serangga bervariasi. Kategori intraspesies capung (Odonata) berkisar antara 0.00-0.035 sedangkan kategori interspesies (interspecific pdistance) berkisar antara 0.03-0.186 (Laltanpuii et al., 2014), Untuk lepidoptera jenis ngengat (Heterocera) variasi intraspesies berkisar antara 00.097 dan variasi interspesies berkisar antara 0.016-0.228, sedangkan pada lepidoptera jenis kupu-kupu (Rhopalocera) variasi intraspesies berkisar 0.00 - 0.049 (Schmitt dan Haubrich, 2008; Liu et al., 2014).

Semakin besar nilai jarak genetik ( $p$-distance) diantara populasi atau individu maka semakin terisolasi antara satu dengan lainnya, jarak genetik menunjukan kemungkinan adanya pengaruh isolasi geografis terhadap suatu populasi (Schmitt dan Haubrich, 2008; Laltanpuii et al., 2014). Perbandingan ke dua sampel di berbeda lokasi (Gunung Tumpa dan Gunung Dua-Sudara Bitung) dengan sampel dari GenBank memiliki nilai $p$ distance antara 0.002 - 0.014, dengan begitu sampel ThelenaBB dan ThelenaBT dibandingkan dengan tiga sampel dari GenBank (KF226655.1, EF514456.1, EF514446.1) yang berasal dari lokasi geografi yang berbeda masih tergolong dalam kisaran variasi intraspesies. 
Tabel 1. Matriks p-distance sekuens gen COI Troides helena Sampel ThelenaBT dan ThelenaBB dengan kerabat dekatnya dari GenBank.

\begin{tabular}{llllll}
\hline & $\begin{array}{l}\text { ThelenaBT } \\
\text { (Tumpa) }\end{array}$ & $\begin{array}{l}\text { ThelenaBB } \\
\text { (Bitung) }\end{array}$ & $\begin{array}{l}\text { KF226655.1 } \\
\text { (Malaysia) }\end{array}$ & $\begin{array}{l}\text { EF514456.1 } \\
\text { (India) }\end{array}$ & $\begin{array}{l}\text { EF514446.1 } \\
\text { (Indonesia) }\end{array}$ \\
\hline $\begin{array}{l}\text { ThelenaBT } \\
\text { (Tumpa) }\end{array}$ & & 0.002 & 0.014 & 0.014 & 0.014 \\
\hline $\begin{array}{l}\text { ThelenaBB } \\
\text { (Bitung) }\end{array}$ & 0.002 & 0.012 & 0.012 & 0.012 \\
\hline $\begin{array}{l}\text { KF226655.1 } \\
\text { (Malaysia) }\end{array}$ & 0.014 & 0.012 & & 0 & 0 \\
\hline $\begin{array}{l}\text { EF514456.1 } \\
\text { (India) }\end{array}$ & 0.014 & 0.012 & 0 & & 0 \\
\hline
\end{tabular}

\section{Kesimpulan}

Perbandingan sekuens gen $\mathrm{COI}$ antara sampel ThelenaBT (Gunung Tumpa) dan ThelenaBB (Gunung Dua-Sudara) menunjukan adanya variasi. Variasi ditunjukan dengan adanya perbedaan satu pasang basa nukleotida urutan sekuens sampel dilokasi berbeda. Variasi intraspesies juga ditunjukan pada sampel yang diperoleh dari GenBank (KF226655.1, EF514456.1, EF514446.1), dengan adanya perbedaan 8 pasang basa nukleotida dengan sampel ThelenaBT dan 7 pasang basa nukleotida dengan sampel ThelenaBB. Nilai jarak genetik yang berkisar antara 0,002 0,0014 menunjukkan bahwa, variasi pada gen COI dari sampel yang berbeda lokasi geografi (KF226655.1: Malaysia, EF514456.1: India dan EF514446.1: Indonesia) dengan sampel yang berasal dari lokasi Gunung Tumpa dan Gunung DuaSudara (ThelenaBT dan ThelenaBB) masih tergolong dalam variasi intraspesies.

\section{Daftar Pustaka}

Ashfaq. M., S. Akhtar, A. M. Khan, S. J. Adamowicz dan P. D. N. Hebert. 2013. DNA Barcode Analysis of Butterfly Species from Pakistan Points Towards Regional Endemism. Molecular Ecology Resources. (13)832-843

Basset. Y., R. Eastwood, L. Sam, D. J. Lohman, V. Novotny, T. Treuer, S. E. Miller, G. D. Weiblen, N. E. Pierce, S. Bunyavejchewin, W. Sakchoowong, P. Kongnoo dan M. A. Osorio-arenas. 2012. Cross-continental Comparisons of Butterfly Assemblages in Tropical Rainforests: Implications for Biological Monitoring. Insect Conservation and Diversity doi:10.1111/j.17524598.2012.00205: 1-10

Corpet, F. 1988. Multiple Sequence Alignment with Hierarchical Clustering. NUCL. Acids res. 16(22): 10881-10890.

Davenport. C. 2014. Using DNA Barcodes to Identify and Classify Living Things. Cold Spring Harbor Laboratory DNA Learning Center: United States.
Dharmayanti. N.L.P. I. 2011. Filogenetika Molekuler: Metode Taksonomi Organisme Berdasarkan Sejarah Evolusi. WARTAZOA Vol. 21 No. 1:1-10

Emily. A. R., G. A. Blagoev, P. D. N. Hebert dan S. J. Adamowicz. 2009. Prospects for using DNA barcoding to identify spiders in species-rich genera. ZooKeys doi:10.3897/zookeys.16.239. 16:27-46.

Folmer. O., M. Black, W. Hoeh, R. Lutz, dan R. Vrijenhoek. 1994. DNA primers for amplification of mitochondrial cytochrome c oxidase subunit I from diverse metazoan invertebrates. Molecular Marine Biology and Biotechnology (1994) 3(5): 294-299.

Handoyo. D dan A. Rudiretna. 2000. Prinsip Umum dan Pelaksanaan Polymerase Chain Reaction (PCR). Unitas 9(1):17-29

Hawkes. N. J., R. W. Janes, J. Hemingway dan J.Vontas. 2004. Detection of Ressistanceassociated Point Mutations of Organophosphateinsensitive Acetylcholinesterase in the Olive Fruit Fly, Bactrocera oleae (Gmelin). Pesticide Biochemistry and Physiology 81: 151-163

Hebert. P. D. N., A. Cywinska, S. L. Ball dan J. R. deWaard. 2003 Biological identifications through DNA barcodes. Proc. R. Soc. Lond. B 2003 270: 313-321.

Hebert. P. D. N., E. H. Penton, J. M. Burns, D. H. Janzen dan W. Hallwachs. 2004. Ten Species in one: DNA Barcoding Reveals Cryptic Species in the Neotropical Skipper Butterfly Astraptes fulgerator. Pnas. 101(41):14812-14817

Hedrick. P. W dan S. T. Kalinowski. 2000. Inbreeding Depression in Conservation Biology. Ecol. Syst. 2000. 31: 139-162

Jin. Q., H. Han, X. Hu, X. Li, C. Zhu, S. Y. W. Ho dan R. D. Ward, A. Zhang. 2013. Quantifying Species Diversity with a DNA Barcoding- Based Method: Tibetan Moth Species (Noctuidae) on the Qinghai-Tibetan Plateau. PLoS ONE 8: e64428:113.

Kearse. M., R. Moir, A. Wilson, S. S.Havas, M. Cheung, S. Sturrock, S. Buxton, A. Cooper, S. Markowitz, C. Duran, T. Thierer, B. Ashton, P. Meintjes, dan A. Drummond. 2012. Geneious Basic: an Integrated and Extendable Desktop 
Software Platform for the Organization and Analysis of Sequence Data. Bioinformatics Applications Note Vol. 28 no. 12 2012, pages 1647-1649.

Kolondam. B. J., E. Lengkong, J. Polii-Mandang, A. Pinaria, dan S. Runtunuwu. 2013. Barcode DNA Anthurium Gelombang Cinta (Anthurium plowmanii) berdasarkan gen rbcL dan matK). Jurnal bioslogos, februari 2013, vol. 3 nomor 1:17-25.

Koneri. R dan Saroyo. 2012. Distribusi Dan Keanekaragaman Kupu-Kupu (Lepidoptera) di Gunung Manado Tua, Kawasan Taman Nasional Laut Bunaken, Sulawesi Utara. Jurnal Bumi Lestari, Volume 12 No. 2:357 - 365

Kurniawan. A., N. K. E. Undaharta dan I. M. R. Pendit. Asosiasi Jenis-jenis Pohon Dominan di Hutan Dataran Rendah Cagar Alam Tangkoko, Bitung, Sulawesi Utara. Biodiversitas ISSN: 1412-033x volume 9, nomor 3:199-203.

Laiho. J dan G. Stahls. 2013. DNA Barcodes Identify Central Asian Colias Butterflies (Lepidoptera, Pieridae). ZooKeys 365: 175-196 (doi:10.3897/zookeys.365.5879)

Laltanpuii. N., S. Kumar dan M. T. Mathai. 2014. Molecular and Phylogenetic Analysis of the Genus Orthetrum (Odonata: Anisoptera: Libellulidae) using Mitochondrial $\mathrm{COI}$ gene. Science Vision 14(3): 152-257

Lamatoa. D. C., R. Koneri, R. Siahaan dan P. V. Maabuat. 2013. Populasi Kupu-kupu (Lepidoptera ) di Pulau Mantehage, Sulawesi Utara. Jurnal IImiah Sains Vol. 13 No. 1:52-56

Liu. X. F., C. H. Yang, H. L. Han, R. D. Ward dan A. Zhang. 2014. Identifying Species Of Moths (Lepidoptera) from Baihua Mountain, Beijing, China, using DNA Barcodes. Ecol evol. 4(12): 2472-2487 (doi: 10.1002/ece3.1110)

Lubenow. H., M. Scherer dan D. Herold. 2008. Automated Extraction of Forensic Samples Using Established Spin Column Technology on the QIAcube. RdanD Department QIAGEN: Germany

Matern. A., K. Desender, C. Drees, E. Gaublomme, W. Paill dan T. Assmann. 2009. Genetic Diversity and Population Structure of the Endangered Insect Species Carabus variolosus in its Western Distribution Range: Implications for Conservation. Conserv Genet (doi: 10.1007/s10592-008-9606-1)

Murray. R. K., D. A. Bender, K. M. Botham, P. J. Kennelly, V. W. Rodwell dan P. A. Weil. 2014. Biokimia harper edisi 29. Penerbit buku kedokteran: jakarta. (402)

Nadeau. N. J., C. Pardo-diaz, A. Whibley, M. Supple, R. Wallbank, G. C. Wu, L. Maroja, L. Ferguson, H.
Hines, C. Salazar, R. French-constant, M. Joron, W. O. Mcmillan dan C. D. Jiggins. 2015. The Origins of a Novel Butterfly Wing Patterning Gene from Within a Family of Conserved Cell Cycle Regulators. BioR 11(5) 1-33 (doi: http://dx.doi.org/10.1101/016006)

Ngatimin. S. N. A., A. P. Saranga, N. Agus, A. Achmad dan I. Ridwan. 2014. Two Artificial Diet Formulations For Troides Helena Linne Larvae (Lepidoptera: Papilionidae) In BantimurungBulusaraung National Park, South Sulawesi. International Journal of Scientific dan Technology Research volume 3, issue 7. Issn 2277-8616:170-173

Nurjannah, S.T. 2010. Biologi Troides helena helena dan. Troides helena hephaestus (Papilionidae) di. Penangkaran (Tesis). Bogor: Institut Pertanian. Bogor.

Pujawan. A. A. N. O., T. S. Nindhia dan I. G. N. K. Mahardika. 2012. Identifikasi Spesies Udang Mantis (Stomatopoda) Di Perairan Pemuteran Dengan Menggunakan Gen Cytochrome C Oxidase Subunit-1 Dari Dna Mitokondria. Indonesia medicus veterinus ISSN: 2301-7848. 1(2):268-280

Sambrook. J dan D. W. Russell. 2006. Agarose Gel Electrophoresis Protocol. Csh Protocols (doi: 10.1101/pdb.prot4020)

Schmitt. T. dan K. Haubrich. 2008. The Genetic Structure of the Mountain Forest Butterfly Erebia euryale Unravels the Late Pleistocene and Postglacial History of The Mountain Coniferous Forest Biome in Europe. Molecular ecology 17(9): 2194-2207 (doi: 10.1111/j.1365294x.2007.03687.x)

Simonsen. T. J., E. V. Zakharov, M. Djernaes, A. M. Cotton, R. I. Vane-wright dan F. A. H. Sperling. 2010. Phylogenetics and Divergence Times of Papilioninae (Lepidoptera) with Special Reference to the Enigmatic Genera Teinopalpus snd Meandrusa. Cladistics 26: 1-25 (doi: 10.1111/j.1096-0031.2010.00326.x)

Tallei, T.E. dan B.J.Kolondam. 2015. DNA barcoding of Sangihe Nutmeg (Myristica fragrans) using matK gene. HAYATI Journal of Biosciences 22(1): (41-47. DOI: 10.4308/hjb.22.1.41)

Wowor. M. M., M. A. Langi, F. B. Saroinsong dan W. Nurmawan. 2014. Kondisi Biofisik Gunung Tumpa Sebagai Taman Hutan Raya (TAHURA). cocos ejournal.unsrat. Vol 4, No 2:1-1

Zhou. T., W. Gu dan C. O. Wilke. 2010. Detecting Positive and Purifying Selection at Synonymous Sites in Yeast and Worm. Mol.Biol.Evol. 27(8): 1912-1922 